\title{
Water stress effects on yield and Quality of sugar beet crop in sandy soils
}

\author{
Amr M.A EL-Darder ${ }^{1}$ Mohsen A. Gamaa ${ }^{2}$, Mahmoed. A. Sayed ${ }^{3}$ and Mohamed.Z. Kamel ${ }^{4}$
}

\begin{abstract}
The present investigation was carried out during the two growing seasons of 2014/2015 and 2015/2016 at the farm of Nubaria sugar and reefing company. El-Bohera Governorate, Egypt to study the effect of water stress regimes $(60 \%, 80 \%$, and $100 \%$ of irrigation water requirement (IWR) on growth and yield quality of sugar beet plant grown under drip and sprinkler irrigation systems and sandy soil conditions. Results revealed that drip irrigation system with $80 \%$ of (IWR) recorded the highest significant leaf area index, sucrose percentage, purity percentage and extractable sugar percentage in both seasons of sugar beet crop. While application of sprinkler irrigation at $100 \%$ (IWR) gave the heaviest root weight, root Number/fed, purity percentage and root yield in both growing seasons.

Drip irrigation system with $1322 \mathrm{~m}^{3} /$ fed water $(60 \%$ of IWR) give the best satisfy yield and good quality of sugar beet crop under sandy soil and the experimental condition.
\end{abstract}

Key words: sugar beet - drip-sprinkler - water stressgrowth - yield.

\section{INTRODUCTION}

Sugar beet is the second sugar crop after sugar can for the production process of sugar in Egypt. Water is one of the most essential parameters for crop production. So, the challenge facing the growers of sugar beet is to optimize (IWR) with suitable irrigation methods and the water regime needed.

There is a directed relation between crop yield and water use by plants. Agriculture in arid regions has special aspects; so, agriculture is limited by water and irrigation therefore, agriculture practices are organized for optimal water use and maximum yield per unit volume of used water. Irrigation system is one of the methods which have an important role in suitable use of water and increasing water use efficiency. Irrigated agriculture is still practiced in many areas in the world with complete disregard to basic principles of resource conservation and sustains ability. Therefore irrigation water management in an area of water scarcity will have to be carried out most efficiently, aiming at saving water and at maximizing is productivity. Irrigation is applied to avoid water deficits that reduce crop production. The process of crop water use has two main components. One due to evaporation losses from the soil and the crop, usually called evapotranspiration, and the other that includes all the losses resulting from the distribution of water to the field.( English, 1990 Fereres and Soriano, 2007) Irrigation system are selected, designed and operated to supply the irrigation requirements of each crop on the farm while controlling deep percolation, run off, evaporation, and operation losses, to establish a sustainable production process. To crop with scare supplies, deficit irrigation defined as the application of water below full crop - water requirements, is an important tool to achieve the goal of reducing irrigation water use. There is potential for improving water productivity in many field crops and there is sufficient information for defining the best deficit irrigation strategy for many situations. Irrigation is necessary to provide moisture for seed germinate and in many areas to control salinity over irrigation at early stages may tend to leach nitrates, and enhance seeding diseases. During periods of growth, there is several light irrigation may be more important, At midseason sugar beet plants option most of their moisture from the upper 3 feet of soil and heavier irrigations are required to supply this moisture. Moderate moisture stress just before harvest tends to increase sugar percentage without limited sugar yield per acre (Kirda, 2002). Sugar beet (Bata Valgaris L.) has been recognized as an important essential plant nutrient for more than a century. The past go years have brought marked advanced in the capacity to manufacture and apply nitrogen as commercial fertilizers the marked increases in $\mathrm{N}$ - fertilizers application to the soil have raised concern about the environmental important of $\mathrm{N} \mathrm{T}$ escapes from the root zone (Di and Cameron, 2002). The rate of $\mathrm{N}$ in plant nutrition has been recognized to be connected to the production of vigorous vegetation growth crop response to $\mathrm{N}$ fertilization can be expressed in terms of highest yield and improved crop quality. Some of the most significantly advances in nitrogen fertilization of crop have been occurred during its beneficial capacity to provide both in come from the harvested root as well as live stock in the form of above - ground biomass (tops ) and root processing by products such as pulp and molasses (Stev et al., 2008). There for, the present investigation aimed to study water stress effects $(60 \%, 80 \%$, and $100 \%$ from

\footnotetext{
${ }^{1}$ Nubaria sugar Company

${ }^{2}$ Soil and water Dept. Fac. Agric. Asyut Univ. Egypt.

${ }^{3}$ Soil water and Environment Res. Institute

${ }^{4}$ Agricultural consultant of Nubaria Sugar Company

Received October 02,2017, Accepted December 12, 2017
} 
irrigation water requirement on yield and quality of sugar beet plants in sandy soils under condition of drip and sprinkler irrigation systems

\section{MATERIALS AND METHODS}

Two field experiments were carried out in 2014/2015 and 2015/2016 seasons at Nubaria sugar factory , El-Behiera Governorate , Egypt to study the effects of water stress on yield and quality of sugar beet crop in sandy soil Nubaria sugar factory is situated at $30^{\circ}, 38^{\circ}, 00.4^{\prime \prime} \mathrm{N}$ latitude, $30^{\circ}, 13.35,9^{\prime \prime} \mathrm{E}$ longitude and the altitude is $28 \mathrm{~m}$ above the sea level.

Soil samples were collected from three depths (0-20, 20-40 and 40-60 cm) to determine the main soil physical and chemical properties at the experimental site. The soil physical parameters (particle size distributions and soil texture class) were determined according to FAO (1970), soil-moisture constants (soil field capacity, F.C.; wilting point. W.P.; and available water, A.W.) Were determined on mass basis by a pressure extractor apparatus, and soil bulk density values were determined in undisturbed soil samples using the core method (Black and Hartge, 1986). The soil chemical parameters (electrical conductivity (EC), soil reaction $(\mathrm{pH})$, soluble cations, and anions), organic matter, and total calcium carbonate were determined according to Page et al. (1982). The soil main physical and chemical properties are listed in Tables 1 and 2 .

Irrigation water used in the experiment was pumped from Nubaria canal. The chemical analysis of irrigation water According to A. O.A.C.(1970)is given in table (3).

\section{Experimental Design}

A split-split plot design with three replications was used for each irrigation system.The water stress treatments occupied the main plots، while the sub plots

Table 1. Soil Particle size distribution, Field capacity, wilting point, available water, and bulk density values of the experimental site

\begin{tabular}{ccccccccc}
\hline $\begin{array}{c}\text { Soil depth } \\
(\mathrm{cm})\end{array}$ & \multicolumn{2}{c}{ Particle size distribution $\%$} & $\begin{array}{c}\text { Texture } \\
\text { class }\end{array}$ & $\begin{array}{c}\text { Field } \\
\text { Capacity } \\
(\%)\end{array}$ & $\begin{array}{c}\text { Wilting } \\
\text { Point } \\
(\%)\end{array}$ & $\begin{array}{c}\text { Available } \\
\text { water } \\
(\%)\end{array}$ & $\begin{array}{c}\text { Bulk density } \\
\left(\mathrm{g} \mathrm{cm}^{-3}\right)\end{array}$ \\
\hline $0-20$ & 94.5 & 3.5 & 2.0 & Sandy & 13.25 & 5.50 & 7.75 & 1.65 \\
$20-40$ & 95.0 & 3.3 & 1.7 & Sandy & 14.25 & 4.90 & 9.35 & 1.56 \\
$40-60$ & 95.7 & 3.0 & 1.3 & Sandy & 14.50 & 4.30 & 10.20 & 1.44 \\
\hline
\end{tabular}

Table 2. Main soil chemical properties of the the experimental site before sowing

\begin{tabular}{|c|c|c|c|c|c|c|c|c|c|c|c|c|}
\hline \multirow{2}{*}{$\begin{array}{c}\text { Soil } \\
\text { depth } \\
(\mathrm{cm})\end{array}$} & \multirow{2}{*}{$\begin{array}{c}\mathrm{EC} \\
\mathrm{dS} \mathrm{m}^{-1}\end{array}$} & \multirow{2}{*}{$\begin{array}{c}\mathrm{pH} \\
1: 2.5\end{array}$} & \multirow{2}{*}{$\begin{array}{c}\text { Total } \\
\mathrm{CaCO}_{3} \\
\%\end{array}$} & \multicolumn{4}{|c|}{ Soluble cations $\left(\right.$ meq $\left.\mathrm{L}^{-1}\right)$} & \multicolumn{4}{|c|}{ Soluble anions $\left(\mathrm{meq} \mathrm{L}^{-1}\right)$} & \multirow{2}{*}{$\begin{array}{c}\mathrm{OM} \\
\%\end{array}$} \\
\hline & & & & $\mathrm{Ca}^{2+}$ & $\mathrm{Mg}^{2+}$ & $\mathrm{Na}^{+}$ & $\mathrm{K}^{+}$ & $\mathrm{CO}_{3}^{2-}$ & $\mathrm{HCO}_{3}^{-}$ & $\mathrm{Cl}^{-}$ & $\mathrm{SO}_{4}^{2-}$ & \\
\hline $0-20$ & 1.46 & 8.23 & 4.9 & 6.23 & 2.24 & 3.44 & 0.51 & - & 0.93 & 1.88 & 9.61 & 1.025 \\
\hline $20-40$ & 1.56 & 8.11 & 5.8 & 6.45 & 2.26 & 3.76 & 0.58 & - & 1.15 & 2.05 & 9.85 & - \\
\hline $40-60$ & 1.63 & 7.97 & 4.2 & 6.65 & 2.29 & 3.91 & 0.65 & - & 1.33 & 2.01 & 10.16 & - \\
\hline Average & 1.55 & 8.10 & 4.97 & 6.44 & 2.26 & 3.70 & 0.58 & & 1.14 & 1.98 & 9.87 & 1.03 \\
\hline
\end{tabular}

were assigned for the two organic fertilization levels. Meantime, the three nitrogen levels were randomly distributed in the sub-sub plots. Multi-green variety viz. Gazelle imported from Germany water sown on the first week of October of each season .seeds was on ridges 60 $\mathrm{cm}$ apart and $20 \mathrm{~cm}$ between hills. Each sub - sub plot size was $15 \mathrm{~m}^{2}$ (125 plants).

The sugar beet plants were harvested 190-200 days after sowing in both seasons. Ten guarded plants were selected at random from each treatment of three replications.

\section{Crop water-use parameters:}

Reference Evapotranspiration (ETo): Data from the agricultural weather station were available and the Penman-Monteith method was used in CROPWAT was used to calculate ETo.

The ETo values were calculated as follows:

Penman-Monteith Method: Penman-Monteith equation is given as:

$$
0.408 \Delta(R n-G)+\gamma[900 /(T+273)] U_{2}\left(e_{s}-e_{a}\right)
$$

where:

$\mathrm{Rn}=$ net radiation $\left(\mathrm{MJ} \mathrm{m}^{-2} \mathrm{~d}^{-1}\right)$

$\mathrm{G}=$ soil heat flux $\left(\mathrm{MJ} \mathrm{m}^{-2} \mathrm{~d}^{-1}\right)$

$\Delta=$ slope of vapor pressure and temperature curve $\left(\mathrm{kPa}{ }^{\circ} \mathrm{C}^{-1}\right)$

$\gamma=$ psychrometric constant $\left(\mathrm{kPa}^{\circ} \mathrm{C}^{-1}\right)$

$\mathrm{U}_{2}=$ wind speed at $2 \mathrm{~m}$ height $\left(\mathrm{ms}^{-1}\right)$

$\mathrm{e}_{\mathrm{s}}-\mathrm{e}_{\mathrm{a}}=$ vapor pressure deficit $(\mathrm{kPa})$

$\mathrm{T}=$ mean daily air temperature at $2 \mathrm{~m}$ height $\left({ }^{\circ} \mathrm{C}\right)$ model (Smith, 1992), described by Allen et al. (1998) 
Table 3. Chemical characteristics of irrigation water

$\mathrm{EC}\left(\mathrm{dsm}^{-1}\right) \quad \mathrm{pH} \quad$ Soluble cations $\left(\mathrm{meq} \mathrm{L}^{-1}\right)$

$$
\begin{array}{llllllll}
\mathrm{Ca}^{2+} & \mathrm{Mg}^{2+} & \mathrm{Na}^{+} & \mathrm{K}^{+} & \mathrm{CO}_{3}{ }^{2-} & \mathrm{HCO}_{3}{ }^{-} & \mathrm{Cl}^{-} & \mathrm{SO}_{4}{ }^{2-}
\end{array}
$$

SAR

1.18

7.14

$\begin{array}{llll}2.98 & 2.0 & 1.0 & 0.0\end{array}$

1.3

$1.25 \quad 2.98$

12.1

Table 4. average Agro- meteorological data of the experimental site during the growth period at Wadi- ElNatrun station

Month

October 2014

November 2014

December 2014

January 2015

February 2015

March 2015

April 2015

Average

$\begin{array}{cc}\begin{array}{c}\text { Min } \\ \text { temperature } \\ \left({ }^{\circ} \mathrm{C}\right)\end{array} & \begin{array}{c}\text { Max } \\ \text { temperature }\end{array} \\ 16.24 & \left({ }^{\circ} \mathrm{C}\right) \\ 11.67 & 28.79 \\ 11.10 & 22.44 \\ 7.89 & 21.44 \\ 8.09 & 17.74 \\ 9.48 & 18.33 \\ 13.12 & 21.78 \\ 11.08 & 27.16 \\ \end{array}$

$\begin{gathered}\text { Relative } \\ \text { humidity } \\ (\%)\end{gathered}$
50.26
57.59
59.14
50.54
50.00
49.53
48.28
52.19

Wind speed

$(\mathrm{m} / \mathrm{sec})$

2.24

2.13

2.39

2.88

2.86

3.30

2.43

2.60
Sun shine

(hr)

9.02

7.76

6.50

6.79

7.47

8.34

9.41

7.90
ETo

(mm/day)

$\mathrm{q}=$ emitter discharge $(\mathrm{L} / \mathrm{h})$

AIW = applied irrigation water $(\mathrm{cm})$

While, the irrigation time for sprinkler irrigation water was calculated

according to the equation as follows :

$$
\text { Irrigation time }(h)=\frac{A I W}{A R}
$$

Where:

$\mathrm{AR}=$ application rate $(\mathrm{mm} / \mathrm{h})$

$$
A I W=\frac{E T o \times K c I}{E a(1-L R)}
$$

Where:

$\mathrm{AIW}=$ depth of applied irrigation water in $\mathrm{mm}$

$\mathrm{ETo}=$ Reference evapotranspiration, $\mathrm{mmd}^{-1}$

$\mathrm{Kc}=$ crop coefficient (for sugar beet crop as reported by FAO, Allen et al. 1998).

I= irrigation intervals (days)

$\mathrm{Ea}=$ irrigation application efficiency of the drip and sprinkler irrigation system.

L.R = leaching requirements,

Irrigation time for drip irrigation system was determined before an event by measuring the actual emitter discharges according the equation given by Ismail (2002) as follows:

$$
t=\frac{A I W \times A}{q}
$$

Where:

$\mathrm{t}=$ irrigation time $(\mathrm{h})$

$\mathrm{A}=$ wetted area $\left(\mathrm{cm}^{2}\right)$

$$
A r=\frac{1000 \times Q}{L l \times L s}
$$

$\mathrm{Q}=$ sprinkler discharge $\left(\mathrm{m}^{3} / \mathrm{h}\right)$

$\mathrm{L}_{\mathrm{L}}=$ distance between lateral $(\mathrm{m})$

$\mathrm{Ls}=$ distance between sprinkler $(\mathrm{m})$

Water utilization efficiency (WUtE): The WUtE values were calculated according to Jensen (1983) as follows:

$$
W U t E=\frac{\text { Sugar beet yield }(\mathrm{kg} / \mathrm{fed})}{\text { Applied irrigation } \text { water }\left(\mathrm{m}^{3} / \mathrm{fed}\right)}
$$

Determinations related to sugar beet crop as follow:

\section{A-Growth traits:} random from each sub-sub plot and topped to determine the following traits in both seasons:

1-Root weight $(\mathrm{kg})$

2-Leaf area index (LAI): Leaf area index $[(\mathrm{LAI})=$ unit leaf area per plant $\left(\mathrm{cm}^{2}\right) /$ plant ground area $\left.\left(\mathrm{cm}^{2}\right)\right]$ was determined after 90 days from planting
At harvesting, a sample of ten plants was taken at 
according to Watson (1958) and leaf area was determined using area meter, ATA60, Model 3100

\section{B-Yield quality traits:}

At harvesting, a sample of ten roots was taken at random from each sub-sub plot and cleaned to determine the following traits in both seasons:

1-Sucrose percentage: was determined by using sacharometer lead acetate extract of fresh macerated roots according to Carruthers and Oldfield (1960).

2 -Extractable sugar percentage (ES\%): According to Renfield et al. (1974), it was determined using the following formula:

$\mathrm{ES} \%=\operatorname{pol}-[0.343(\mathrm{~K}+\mathrm{Na})+0.094 \alpha$-amino $\mathrm{N}+0.29]$ where $\mathrm{Pol}=$ sucrose percentage.

3 -Juice purity percentage $(\mathbf{Q Z})=(\mathrm{ES} \% / \mathrm{pol}) \times 100$ and

4 -Impurities percentage $=[0.343(\mathrm{~K}+\mathrm{Na})+0.094 \alpha$ amino $\mathrm{N}+0.29$ ] Were determined according to Renfield et al.( ( $9 \vee \varepsilon)$.

\section{C-Yield:}

At harvesting, the guarded ridges of sugar beet in each sub-sub plot were up-rooted, topped, cleaned and weighed to determine:

1 -Root number/fed.

2 -Root yield (ton/fe).

2-White sugar yield $($ ton/fed) $=$ root yield (ton/fed) $\mathrm{x}$ (Extractable sugar \%/100).

\section{Statistical analysis}

Collected data under each irrigation system were subjected to normal statistical analysis according to Snedecor and Cochran (1989). Treatment mean comparisons were done using least significant difference (LSD) at 5\% level of probability. After homogeneity test, combined analysis was done to compare between the two irrigation systems.

\section{RESULTS AND DISCUSSION}

\section{A-Applied irrigation water:}

Growth stage total applied of irrigation water in $\mathrm{mm}$ during the growing seasons are presented in Table 4 . Results showed the normal trend of increasing applied irrigation water with the advance in plant growth and the decrease at the ripening stage. The highest growth stage value of applied irrigation water occurred during Mid-season in both Irrigation systems for all irrigation treatments. The total amount of applied irrigation water for 60,80 , and $100 \%$ of ETo irrigation treatments were $1589.3,2223.0$ and $2880.8 \mathrm{~mm}$ in the Sprinkler irrigation system , and were 1322.0, 1943.5, and 2505.0 $\mathrm{mm}$ in the Drip irrigation system, respectively.

\section{B-Effect of water stress on root weight:}

Results in table 6 showed that mean root weight, sucrose, purity and impurities percentages as well as root and white sugar yields were significantly affected by increasing water deficit from $100 \%$ up to $60 \%$ of the irrigation water requirements. The highest LAI value under drip irrigation resulted from $80 \%$ of IWR. These results are in accordance with those obtained by Hosseinpour et al (2006.a) Also Watson (1952) and Good man (1968) who reported that the size longevity of sugar beet leaf canopies strongly influenced by soil moisture and soil fertility. Decreasing the amount of irrigation water from $100 \%$ to $80 \%$ and $60 \%$ of IWR under drip irrigation significantly decreased mean root weight by 8.04 and $26.79 \%$ in the $1^{\text {st }}$ season and 6.78 and $20.34 \%$ in the $2^{\text {nd }}$ season. Under sprinkler irrigation the decrease in mean root amounted to 4.0 and $22 \%$ in the $1^{\text {st }}$ season and 7.41 and $27.78 \%$ in the $2^{\text {nd }}$ season, respectively. Sugar beet plant with $80 \%$ of irrigation water requirements (IWR) recorded the highest percentage of sucrose (20.17 and 20.08\%), purity $(85.72)$ and $80.57 \%)$ and extractable sugar (17.30 and $16.23 \%$ ) under drip irrigation in the first and second seasons, respectively. However, under sprinkler irrigation, juice quality trait values fluctuated among the three irrigation levels during the two growing seasons. Data revealed that application of 80 of (IWR) gave the highest values of extractable sucrose percentage under both irrigation systems. These results are in agreement with those reported by Roberts et al (1980) who they mentioned that deficit irrigation usually increases percent of sucrose in the root Hong and miller (1986) found that sugar concentration in well watered crop rises steadily through the growing season often leveling off before the harvest between 15 and 18\% (9 sugar per100g fresh roots). In water stressed crops it rises more quickly, and under severe stress condition in can be $5 \%$ higher than in unstressed crops. Roots number was significantly affected by the irrigation water levels only under sprinkler irrigation system during the two growing season (table 6).

The conclusion of the previous discussion can briefly include the flowing three points

- Irrigation sugar beet plants with $2880 \mathrm{~m} 3 / \mathrm{fed}$ (100\%of IWR) recorded the highest and significant harvested roots number in the first season (22.20) thousand root /fed and in the second season (21.31 thou sand $\operatorname{root} /$ fed).

-Increasing water deficit from $100 \%$ to $60 \%$ of IWR significantly decreased root and white sugar yields under both irrigation systems during the two growing seasons (table5). Root yield retlection amounted to 26.67 and $25.52 \%$ in the first season and 20.29 and $30.45 \%$ in the second season under 
drip irrigation system, however the decrease in sugar yield accompanying high water deficit might have been due to the decrease in root yield as well as extractable sugar percentage as mention before

Table 5. the amounts of the applied water for the three water regimes, \% of $\mathbf{E T}_{\mathrm{o}}$ (average of the two growing season's amount of water $\left(\mathrm{m}^{3} /\right.$ fed)

Length of growth stage days

Growth stage results on root and white sugar beet yields indicted that yield of drip- irrigated sugar beet with $80 \%$ of IWR nearly matched yield of sprinkler.
30

60

60

30

$$
\text { Initial }
$$

Development

Mid-season

Late-season

Applied of irrigation water $\left(\mathrm{m}^{3} / \mathrm{fed}\right)$

$\begin{array}{llllll}1589.3 & 2223.0 & 2880.8 & 1322.0 & 1943.5 & 2505.0\end{array}$
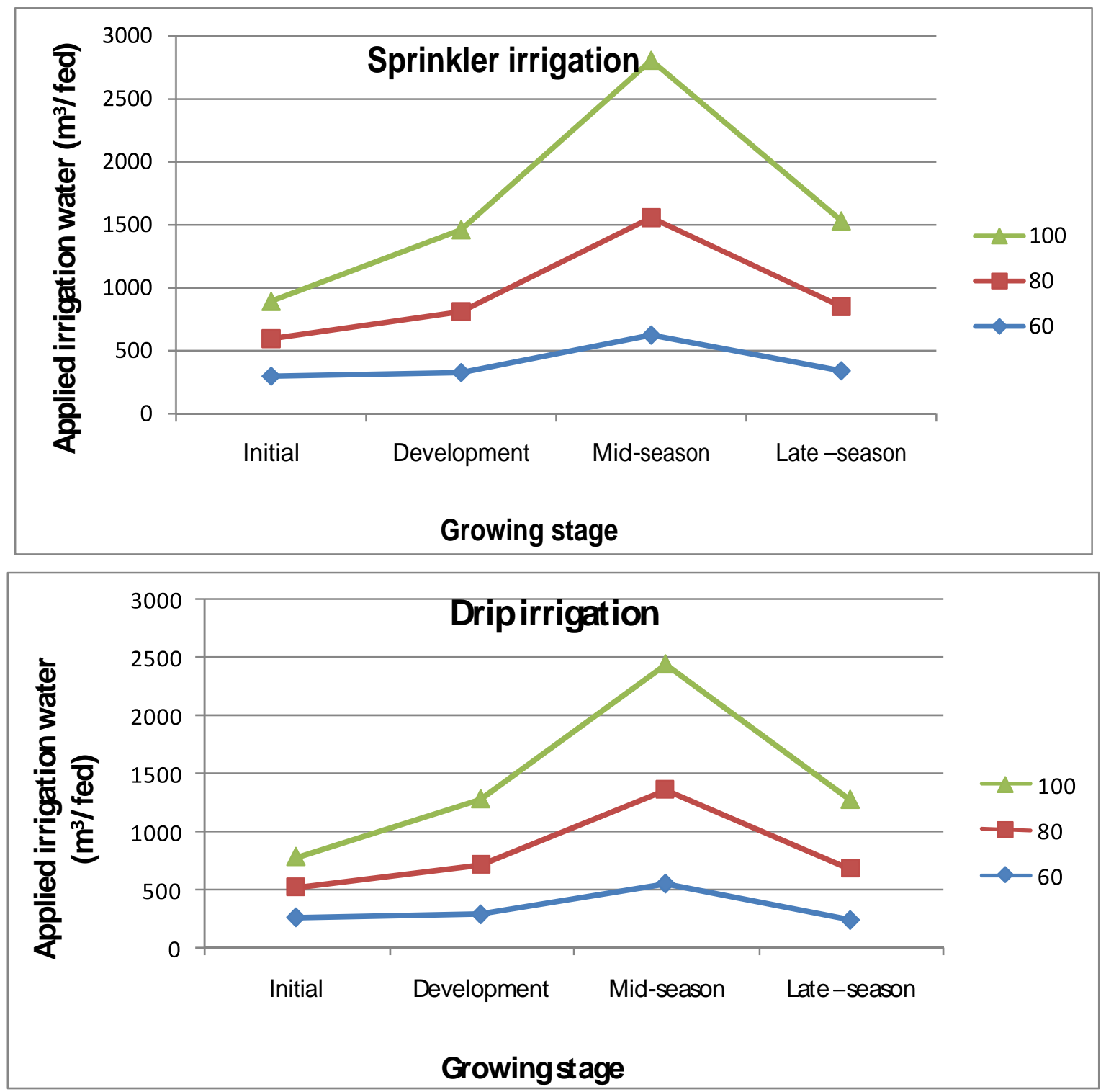

Fig 1. Applied irrigation water (AIW) on different growth stages under sprinkler and drip irrigation systems 


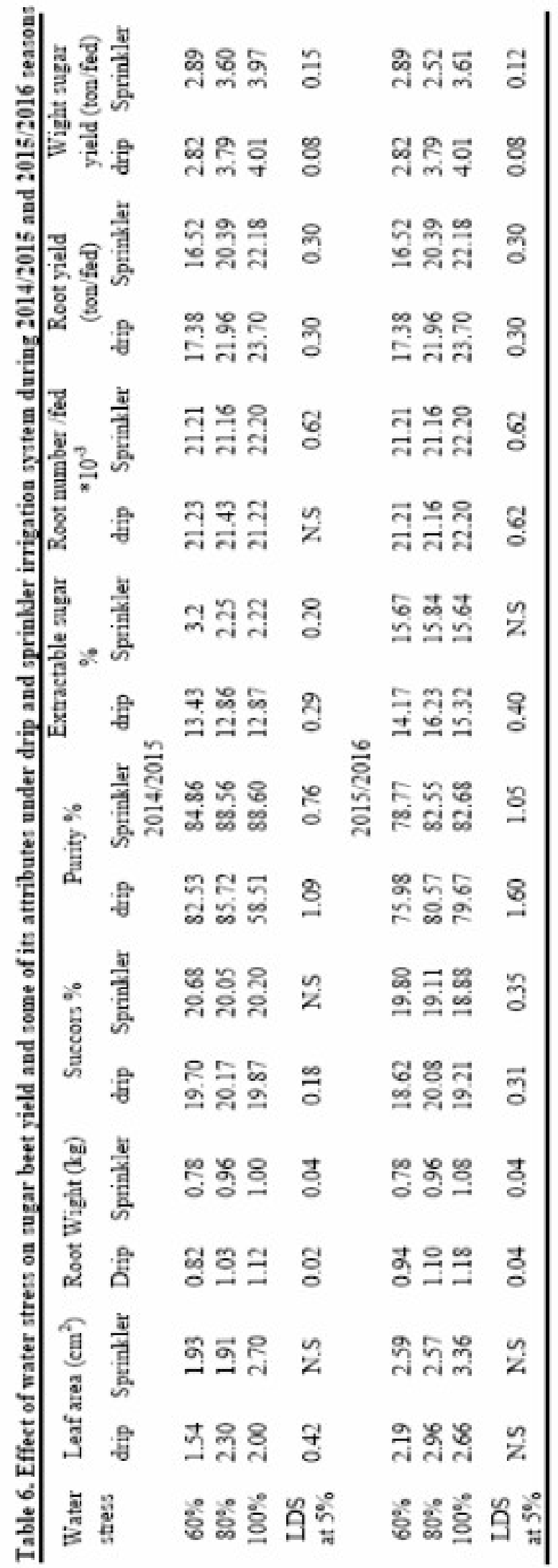


- Irrigated sugar beet with $100 \%$ of IWR during the two growing seasons under drip irrigation gave highest root and white sugar yields and his might be due to the high efficiency of drip irrigation system as compared to sprinkler irrigation system (to Gneti et al., 2003). Data in the same table showed that average across seasons revealed that application of $100 \%$ of IWR gave the highest values of root and white sugar yields/fed under drip and sprinkler irrigation system (table 6).

\section{C-Effect of irrigation system on sugar beet yield.}

Data in Table (7) showed that drip irrigation system in the first season was significantly more efficient than sprinkler irrigation system due to root weight $(\mathrm{kg})$, root yield (ton/fed) and white sugar yield (ton/fed), while in the second season it was significantly more efficient than sprinkler system due to root weight $(\mathrm{kg})$, sucrose $\%$, root number/fed, root yield (ton/fed) and white sugar yield (ton/fed). These results are in agreement with those of Arroyo et al. (1999).

D- Effect of water stress on water use efficiency (WUE).

Table 7. effect of irrigation system on sugar beet yield and some of its attributes during 2014/2015 and 2015/2016 seasons

\begin{tabular}{|c|c|c|c|c|c|c|}
\hline \multirow{2}{*}{ Measurements } & \multicolumn{3}{|c|}{$2014 / 2015$} & \multicolumn{3}{|c|}{$2015 / 2016$} \\
\hline & Drip & Sprinkler & Sig & Drip & Sprinkler & Sig \\
\hline Leaf area index $\left(\mathrm{cm}^{2}\right)$ & 1.90 & 2.15 & $*$ & 2.57 & 2.82 & $*$ \\
\hline Root weight (kg) & 0.97 & 0.88 & $*$ & 1.05 & 0.92 & $*$ \\
\hline Sucrose $\%$ & 19.81 & 20.25 & $*$ & 18.99 & 19.24 & $*$ \\
\hline Juice purity $\%$ & 83.38 & 87.39 & $*$ & 78.20 & 80.31 & $*$ \\
\hline Imparities \% & 3.02 & 2.51 & $*$ & 4.02 & 3.50 & $*$ \\
\hline Extractable sugar \% & 16.78 & 17.71 & * & 15.21 & 15.70 & $*$ \\
\hline Root number $/$ fed $* 10^{-3}$ & 20.27 & 20.49 & * & 21.29 & 20.90 & $*$ \\
\hline Root yield (ton/fed) & 21.00 & 19.60 & $*$ & 22.81 & 20.00 & $*$ \\
\hline White sugar yield (ton/fed) & 3.52 & 3.47 & $*$ & 3.48 & 3.13 & $*$ \\
\hline
\end{tabular}

*indicate significance at 0.05 probability level.

Table 8. Effected of water stress on water use efficiency (WUE) of sugar beet under drip and sprinkler irrigation systems during 2014/2015 and 2015/2016 seasons

\begin{tabular}{ccccc}
\hline Water stress & \multicolumn{2}{c}{ Root yield (WUE) } & \multicolumn{2}{c}{ Sugar yield (WUE) } \\
& Drip & $\begin{array}{c}\text { Sprinkler } \\
\text { Dprinkler }\end{array}$ \\
$60 \%$ & 13.15 & 10.39 & 2.13 & 1.82 \\
$80 \%$ & 11.30 & 9.17 & 1.95 & 1.62 \\
$100 \%$ & 9.46 & 7.59 & 1.60 & 1.38 \\
LDS at 5\% & 0.023 & 0.018 & 0.034 & 0.038 \\
$60 \%$ & 15.19 & $2015 / 2016$ & 2.14 & 1.58 \\
$80 \%$ & 12.40 & 10.11 & 1.94 & 1.48 \\
$100 \%$ & 10.05 & 9.40 & 1.53 & 1.25 \\
LDS at 5\% & 0.012 & 8.01 & 0.007 & 0.021 \\
\hline
\end{tabular}

Results table (8) cleared that mean values of water of water use efficiency based on root and white sugar yields (WUE root and (WUR) Sugar yield were significantly affected by in increasing water deficit from $100 \%$ up to $60 \%$ of the irrigation water requirements (IWR) under both irrigation system in the two growing seasons. Decreasing the amount of irrigation water from $100 \%$ to $80 \%$ and $60 \%$ of IWR under drip irrigation significantly increased WUE of root yield by 16.28 and $28.06 \%$ in the $1^{\text {st }}$ season and by 18.95 and $33.84 \%$ in the $2^{\text {nd }}$ season while under sprinkler irrigation the increase in WUE of root yield amounted to 17.23 and $26.95 \%$ in the $1^{\text {st }}$ season and 14.79 and $20.77 \%$ in the $2^{\text {nd }}$ season, respectively. Drip irrigation sugar beet plant with $60 \%$ of irrigation water requirements (IWR) recorded the highest WUE of while sugar yield by 24.88 and $8.50 \%$ in the first and second season, respectively as compared to $100 \%$ of IWR (table 8 ) the same increase was accursed under sprinkler irrigation with $60 \%$ of IWR by 24.17 and $20.89 \%$ in the $1^{\text {st }}$ and $2^{\text {nd }}$ seasons, respectively as compared to $100 \%$ of IWR. Also, data averaged across seasons revealed that application of 
$60 \%$ of IWR gave the highest values of WUE root and white sugar yields under both irrigation system these results are in agreement with those reported by Hosseinpour et al (2006 a), Esmaeili (2011), Topake (2011) and Morad et al., (2012).

\section{CONCLUSION}

Drip irrigation system with $1322 \mathrm{~m}^{3} /$ fed water $(60 \%$ of IWR) give the best satisfy yield and good quality of sugar beet crop under sandy soil and the experimental condition.

\section{REFERENCES}

A.O.A.C. 1970. "Association of official Agriculture chemists" Methods of Analysis, $11^{\text {th }}$ Edition, wasbington . D.C.

Allen, R. G., L. S. Pereira, D. Raes and M. Smith. 1998. Crop evapotranspiration: Guideline for computing crop water requirements. FAO No 56.

Arroyo, J. M., P. Urban, C. Rojo and F. Gonzalez.1999. Irrigation of sugar beet: com partive studay between drip irrigation and sprinkler. Agric. Revista Agron. 68. (3):90493.

Black, G. and K. Hartge. 1986. Bulk Density. In Klute, A. (ed.): Methods of Soil Analysis. Physical and Mineralogical Methods. ( $2^{\text {ed }}$ Ed.). Soil Science Society of American, Madison, WI, USA. 363-377.

Di, H.J. and K.C.Cameron. 2002.Nitrate leaching in temperate Agroeco system: sources, factors and mitigation strategies nutrient cycling in Agroeco systems. 46:237. 256.

Doorenbos, J. and W.O. Pruitt. 1984. Crop water requirements irrigation and Drainage paper no. 24, FAO, Rom, Italy.144p.

English, M.1990. Deficit irrigation, Analytical farm work .J. Irrigation Dain. Eng. 116:399-412.

Esmaeili M.A. 2011. Evaluation of the effects of water stress and different levels of nitrogen on sugar beet (Betavulgaris). Inter J. boil. 3 (2): 89-93.

FAO. 1970. Physical and Chemical Methods of Soil and Water Analysis. Soils Bull. No. 10, FAO, Rome, Italy.

Fereres, E. and M.A. Soriano.2007. Deficit irrigation for reducing agricultural water use. J. Exp. Bot.58:147-159.

Good Man, P.J. 1968. Physiological analysis of the effects of different soils on sugar beet crops in different years. J. Applied Eco. 5:339-357

Hang, A.N. and D. E.miller. 1986 and physiological responses of potatoes to deficit, high frequency sprinkler irrigation .Argon. 78:436-440.
Hosseinpour, M., A.soroosshzadeh, M.Aghaalikhani, D.F.Taleghani and M.khorramain .2006a. the effect of irrigation in spring on water use efficiency and yield of autumn sown sugar beet .J. sugar beet . 22 (2) : 35-52.

Ismail, S.M. 2002. Design and management of field irrigation system. (in Arabic) 1st Ed. Monshat El-Maref publication Alexandria , Egypt.

Jensen, M.E. 1983. Design and Operation of farm irrigation system. Amer. Soc. Agric. Eng. Michigan, MSA . P827.

Kirda, C. 2002. Deficit irrigation scheduling based on plant Growth stages showing water stress tolerance. Deficit irrigation practices. Water report. 22. p.8.

Morad, M.M. E.I.A. Abdel- Aal and M.A.M. Moursy.2012. water saving with the use of different irrigation system under Egyptian condition. misr .J. Agric. Eng. 29(3)10471066.

Page, A.L., R.H. Miller and D.R. Keeny. 1982. Methods of soil analysis. Amer. Soc. Agr. Inc. Madison, USA.

Renfield, E., A. Emmerich. G.Baumarten, C. Winner and Beiss, U. 1974. Zur Voraussage des Melossezuckers aus Rubenalyses. Zuker. 27:2-15. The Sugar Beet crop, Cock, D.A and R.K Scott. $1^{\text {st }}$ ED. 1993. Chapman \& Hall (World Crop Series), London, UK.

Roberts, S., J.E. Middletons, A.W. Richards, W.H. weaver and L.F. Hall. 1980. sugar beet production under center pivot irrigation with different rates of nitrogen. Bull. Collage Agric. Res. Cent, Washington state unive. 884.p.5.

Snedecor, G.V. and W.G. Cohran.1989. Statistical method 6th ed., Lowa State Univ. Press, Amess،Lowa, USA. p. 593.

Stevens, W.B., W.B. Violett, S.A. skalkg and A.O. 2008. Response of eight sugar beet varieties to increasing nitrogen application: 1 root, sucrose, and top yield .J. sugar beet Res. 45 (3/4):65-83.

Toak, R., S. Suhier, and B.Acar.2011 . Effect of different drip irrigation regimes on sugar beet (beta Vulgraris) yield quality and water use efficiency in middle Arutolian , Turkey . Irrigation. sci. 29: 79-89.

Tognetti, R., M. pallading , A.Minnocci, S. Deifince and Allitino .2003 the response of sugar beet to drip and low pressure sprinkler irrigation in southern Italy, Agric water manage. 60 (2):35 -155.

Vermeirn,L. and G.A. Gopling. 1984. Localized irrigation. FAO, irrigation and drainage paper No. 36, Rome, Italy.

Waston, D.J. 1952 . the physical basis of variation in yield Adu . agric. 4:101-145

Watson, D.J. 1958. The dependence of net assimilation rate on leaf area index. Annal. Botany, London, 85 (22):37- 54. 


\section{الملخص العربي}

\section{تاثير الاجهاد المائي علي المحصول والجودة لمحصول بنجر السكر في الاراضي الرملية}

(Beta vulgaris L)

عمرو محمد عبد السميع، محسن عبد المنعم جامع، محمود عاطف سيد، محمد زكريا كامل

بنجر السكر الذي تم رية بالتنقيط تحت . بر\% من

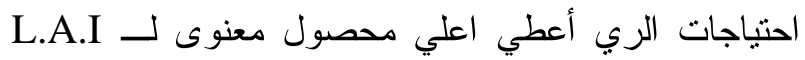

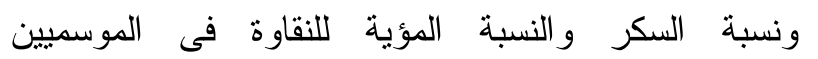
الزر اعيين ونسبة السكر المستخلصة فى الموسم الثاني فقط بينما دع الري بالرش . . 1\% من أحتياجات المحصول

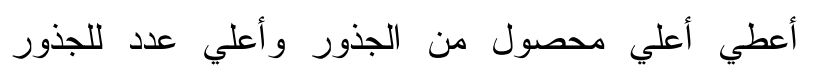

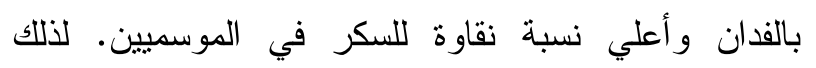
المعاملة الموصي بها هى استخدام الري بالتنقيط مع الري

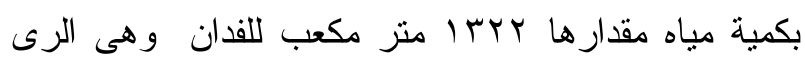

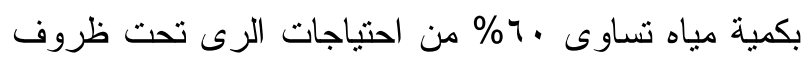
و ادي النطرون محافظة البحيرة - الار اضي الرملية.
أجريت تجربتان حقليتان بمزرعــة البحــوث بـشركة

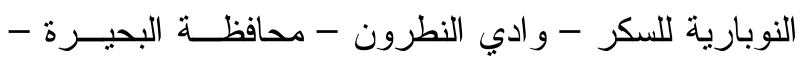

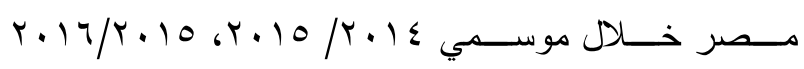
لدر اسة تأثثير الاجهاد IWR المائي على المحصول و الجودة

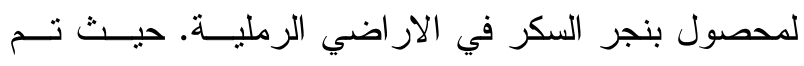

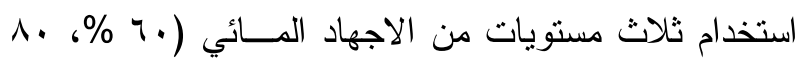
\%، . . 1 \%) من احتياجات الري تحت نظم الري بالتنقيط

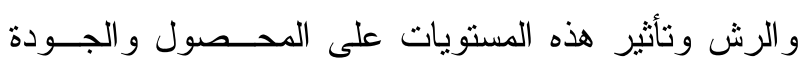

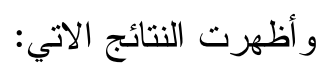

